\title{
The Effect of Implementing a Maintenance Infor- mation System on the Efficiency of Production Facilities
}

\author{
Šlaichová Eva, Maršiková Katerina
}

\begin{abstract}
The paper deals with the topic of facility management focusing on maintenance area and its importance for increasing company competitiveness. The importance of functional company facility management has risen dramatically in recent years. The reason for this is the increased pressure on cost reduction and additional value to the core business of the enterprise. The paper introduces a current theoretical literature-based framework for this topic in order to examine and analyse the supporting activities and processes connected with production facilities and maintenance particularly. The main aim of the paper is to show the importance of a maintenance management information system and the effects of its implementation on the overall equipment efficiency of the facility in the enterprise based on primary data gathered from a selected company. The data was processed in a case study using information from the maintenance department of the selected enterprise in the plastic-processing industry in selected years (2006, 2008, 2009 and 2010). As it shows, this particular system was intended to provide relevant information to workers responsible for adjusting and repairing machines, as well as to the management of the enterprise in order to help them to make the right decision. The results of the data analysis proved the importance of computerized maintenance management information system (CMMIS) implementation in improving Overall Equipment Efficiency (OEE) metrics and the efficient control of its production system.
\end{abstract}

Keywords: facility management, maintenance management, information system, overall equipment effectiveness, CMMIS

\section{INTRODUCTION}

Nowadays a facility management (FM) is an activity including many supporting processes within a company. Facility management can be understood as an area of managerial actions that include wide-range disciplines to ensure the functionality of the business environment in supporting activities connecting together employees, enterprise departments, equipment processes, and technologies. The reason companies have been paying more attention to these activities is in order to find additional options of costs reduction. Moreover, with intense competition and pressure on prices decrease, companies have been seeking ways to become even more flexible, efficient and competitive. One way is to focus on facility management activities including the question of maintenance and to try to find room for possible efficiency improvements.

Historically the application of facility management principles as such started to be included in company management approximately 50 years ago. In the Czech Republic, implementation of FM originated officially at the beginning of the 90's, nevertheless even under communism we 
can find in an organization some departments that dealt with the operation and maintenance of buildings, transport or security. Since the beginning of the 90's, some of the operations within facility management have been provided by external suppliers (outsourced).

The fundamentals purpose of FM is to support organizational strategy and its core business to enhance the organization's economic benefits and core competencies. Therefore, FM should be driven according to organizational strategy, and FM strategy must be a part of the organization's overall strategy. (Vetráková et al., 2013)

\subsection{Facility Management: a Literature Review}

Studying the fundamental literature about facility management, we can find numerous definitions; nevertheless none can be taken as an official international one. Definitions of FM often include terms like 'process', 'service', 'systems', 'information technology' and 'buildings'.

Generally we can say, that facility management is said to address a large scale of different issues related to processes, service activities and building spaces. The scope and specific range of deliverables is considered to vary according to customer requirements, performed both within internal activities and using outsourcing.

Becker (1990) defines FM as the structural activities that are responsible for coordinating all efforts related to planning, design and management of buildings and their systems, their equipment and their fittings, in order to improve the organization's ability to compete successfully in a rapidly changing environment. With this in mind, plant management has to encompass the three cost centres that include local support services and information technology. Alexander (1996) specifies that the purpose of FM is to cover all aspects related to space, environmental control, health and safety and support services. Curcio (2003) says that FM is the integrated management of the multitude of services and processes (concerning the buildings, spaces and people), which are not included in the core business, but which are necessary for the functioning of the organization. Pala e Pristerà (2004) describe FM as the process of design, implementation and control through which it is possible to identify, find and deliver the facilities, in order to provide and maintain a predetermined level of service that can meet business demands in terms of cost a and quality. (Guizzi at al.)

IFMA (International Facility Management Association) (2003) depict FM as a profession that includes multiple disciplines to ensure the functionality of the physical environment through the integration of people, places, processes and technology. Another common definition according to GEFMA (German Facility Management Association) is: "Facility management is defined as the analysis and optimization of all cost-relevant processes relating to buildings, the construction of another facility or any organizational performance not belonging to the principal activity of the organization" (Vetráková et al., 2013).

Moreover, all these activities are backed up by legislation: the international standard EN 12551, identified as norm, ČSN EN 12551 in the Czech Republic.

\subsection{Facility Management and Information Technologies}

According to Šteker (2012) the key role in the implementation of best practice in FM is played by modern information systems. The crucial and fundamental condition for its maximum effectiveness is the process-based management of the enterprise. All these processes cover a huge amount 
of data which needs to be archived and classified according to the different criteria covering the needs of tactical and strategic managerial decisions. The fundamental question for process efficiency management lies with a suitable software application.

Crucial areas covered by Computer Aided Facility Management (CAFM) applications are:

- strategic planning for real estate, business operations, headcount requirements, forecasting future space;

- space planning and management in terms of allocations, inventory, classifications;

- people management as occupant, vendors, staff;

- maintenance management in terms of both demand and scheduled (preventive) maintenance;

- emergency management including disaster planning and recovery, safety information;

- capital project management dealing with construction/renovation, relocation management;

- lease management using property financial data;

- asset management dealing with depreciation, equipment, furniture, telecommunications, cabling;

- building information management integration;

- sustainability in terms of energy performance, building certifications.

CAFM systems are used to ensure that assets are inspected, tested and certified in accordance with statutory and corporate regulations, rules and best practice; corrective actions are taken to correct faults; and records are maintained and can be readily located and made available for inspection. (Schürle, Fritsch, 2000)

\subsection{Providers of Facility Management in the Czech Republic}

Companies can usually draw on outsourcing for FM services. The main aim of using facility management outsourcing as part of company practice is to get this service for such reasons as a higher level of quality, cost saving or insufficient capacity in-house.

In the Czech Republic, we can find several companies providing complex facility services. Within facility management services they offer an integrated package including mainly the management of buildings, production operations and related services in areas of maintenance, service and revisions of technological equipment, energy, cleaning, security and catering.

Table 1 shows the major providers of facility management services in the Czech Republic. 
Tab. 1 - Selected Providers of Facility Management in the Czech Republic. Source: author's own based on companies' information.

\begin{tabular}{|c|c|c|c|c|c|c|}
\hline $\begin{array}{l}\text { FM pro- } \\
\text { vider }\end{array}$ & $\begin{array}{c}\text { Estab- } \\
\text { lishment }\end{array}$ & $\begin{array}{l}\text { Owner- } \\
\text { ship }\end{array}$ & $\begin{array}{l}\text { Number } \\
\text { of Em- } \\
\text { ployees } \\
2011\end{array}$ & $\begin{array}{c}\text { Sales } \\
2011 \text { (in } \\
\text { thousand } \\
\text { CZK) }\end{array}$ & EBIT 2011 & References \\
\hline $\begin{array}{c}\text { ISS Facility } \\
\text { Services } \\
\text { s.r.o. }\end{array}$ & 1996 & foreign & 4430 & 1322071 & 9582000 & $\begin{array}{c}\text { ČNB, RWE } \\
\text { Transgas, } \\
\text { Plzeňský } \\
\text { Prazdroj, } \\
\text { MAKRO, OBI, } \\
\text { Ahold, Baumax }\end{array}$ \\
\hline $\begin{array}{c}\text { OKIN } \\
\text { GROUP, } \\
\text { a.s. }\end{array}$ & 2006 & domestic & 1135 & 653217 & 5626000 & $\begin{array}{l}\text { KB a.s, KOSTAL } \\
\text { CR, spol s.r.o., } \\
\text { ČEZ, a.s., Rai- } \\
\text { feisen bank a.s., } \\
\text { CSOB a.s., Hamé } \\
\text { a.s. }\end{array}$ \\
\hline $\begin{array}{c}\text { Strabag } \\
\text { Property } \\
\text { and Facility } \\
\text { Services }\end{array}$ & 2000 & $\begin{array}{l}\text { Czech/ } \\
\text { German }\end{array}$ & 132 & 314757 & 3057000 & $\begin{array}{c}\text { ČEZ Vinohrady, } \\
\text { Hotel Diplomat, } \\
\text { Metropole Zličín, } \\
\text { PPF Gate }\end{array}$ \\
\hline $\begin{array}{l}\text { Skanska } \\
\text { Facility } \\
\text { s.r.o. }\end{array}$ & 1998 & foreign & 105 & 217746 & -4317000 & $\begin{array}{c}\text { RWE, Český } \\
\text { statistický úřad, } \\
\text { ČTÚ, Me- } \\
\text { diatel spol. s.r.o., } \\
\text { IKEM, Letiště } \\
\text { Václava Havla } \\
\text { Praha }\end{array}$ \\
\hline
\end{tabular}

Table 1 points out that in the Czech business environment we can find both domestic and international companies providing integrated services in the area of facility management to many important Czech customers such as RWE, T-mobile and ČSOB.

\section{MAINTENANCE AND FACILITY MANAGEMENT}

An important part of facility management which significantly supports core activities within a company is the operations maintenance of mechanical equipment. The main tools used for this purpose are monitors, data collectors, analysis and implementation of a system. (Vyskočil, 2010). As the previous chapter of this paper points out, greater effectiveness in any system of FM involves using information technologies. Therefore this chapter aims to show the effects of a maintenance management information system (CMMIS) implementation on the overall equipment effectiveness of the facility in a selected enterprise based on primary data. As Muller at al. (2008) present, function of information technologies in maintenance has increased because of its role in keeping and improving system availability and safety, as well as product quality. They talk about an e-maintenance, representing the concept of e-maintenance that is widespread today in the industry and refers to the integration of the information and communication technologies 
(ICT) within the maintenance strategy and/or plan to face with new needs emerging from innovate ways for supporting production. (Muller at al, 2008).

Maintenance has generally referred to all works carried out to keep and restore an item at a current acceptable standard. Operations and maintenance typically include the day-to-day activities necessary for the building and its systems and equipment to perform their intended function. Operations and maintenance are combined into the common term O\&M because a facility cannot operate at peak efficiency without being maintained; therefore the two are discussed as one.

Services provided within the maintenance area fall into three major categories: (i) preventive maintenance, (ii) routine repairs and (ii) emergency services. Maintenance, testing and inspection schedules are required to ensure that equipment in the facility is operating safely and efficiently, to maximize the life of equipment and reduce the risk of failure. There are also statutory obligations to be met. The work is planned, often using a Computer-aided facility management system. (Wireman, 2005)

Collecting necessary maintenance-cost information enables companies to track engineering information. For example, by using life-cycle costing information, companies can purchase assets with the lowest life-cycle costs rather than lowest initial costs. In order to track overall life cycle costs accurately, all labour, material, contracting, and other miscellaneous costs must be tracked accurately at the equipment level. This tracking is primarily an activity for the maintenance department. In addition to life cycle costing is the need for maintenance budgeting (Wireman, 2005).

According to Jurča (2004) the requirements for the maintenance of assets generally include:

- asset controlling and maintaining in operating and capable (functional) state;

- prevention of failure occurrence and following fault;

- operational corrective maintenance;

- reduction of the environmental impact of machine and equipment operation;

- operational safety assurance;

- maintenance of optimum cost structures.

The emergence of new technologies has changed maintenance service management (Havlík, 2011). The implementation of an electronic system of data collection into the enterprise and the monitoring of maintenance operations can save additional costs to the enterprise and makes the production system work more effectively. Parameters which can influence this effectiveness are as follows: average time of a repair, time between machine failures, total time of failures. These parameters can have a significant influence on the total time of a temporary shutdown of a production line from total production time ('downtime'). This has a direct effect on the enterprise's efficiency. The results of these parameters also depend on the system of data monitoring, their analysis and the implementation of related measurements (Vyskočil, 2010).

Nenadál (2004) points to facility performance measurement methodology, which is necessary to follow if we want to ensure the greatest efficiency of the system:

- Identification and mapping of the process.

- Process description - process modelling. 
- Analysis of the current system of performance measurement.

- Proposed structure of performance measurement metrics.

- Selection of methods for data collection.

- Data processing and presentation of the results.

- Selection of the most suitable system of performance measurement.

- Standardization of the system of performance measurement.

- Continuous improvement of the performance measurement system according to Deming cycle that presents a four-step management method used in business for the control and continuous improvement of processes and products.

\subsection{Overall Equipment Efficiency}

One of the most important and critical matter of facility management is a field maintenance connected with continuous improving of manufacturing systems and its performance evaluation. As Rayes at al. (2010) mention, to measure effectiveness of production equipment companies often use overall equipment effectiveness (OEE). OEE is one of the performance evaluation methods that are commonly used in the production industries. OEE can be considered to combine the operation, maintenance and management of manufacturing equipment and resources. (Dal et al 2000) The OEE metric that originally described by Nakajima (1988), can measure level of equipment effectiveness, and also identify loss elements which are classified into six major groups. These six big losses are breakdown, setup and adjustment losses (downtimes), minor stoppage, reduced speed losses, defect/rework (downtime) and yield losses. (Muchiri, P., Pintelon, L., 2008). Downtimes of equipment are analysed in a research part of this paper.

Overall equipment effectiveness (OEE) and total effective equipment performance (TEEP) are two metrics, closely related and both reporting the overall utilization of facilities, time and material for manufacturing operations. In fact, OEE and TEEP indicate the gap between the ideal and the actual performance. The OEE metric describes the efficiency of the facility. The index consists of three separate independent coefficients: availability, performance and quality. Each part of this metric can point to an aspect of the process that can be monitored and improved. The OEE metric can be used in all types of industries, the challenging target of this metrics is often around $\mathbf{8 5} \%$. (Dwyer, 2008) This indicator is used further in the paper as a target for the machines analysed in the enterprise.

The percentage of scheduled time that the facility is available to operate can be characterized by the coefficient of availability. According to the calculation, the availability is the ratio between the available time and the scheduled time of production. The performance coefficient of the OEE metric can be measured as the amount of parts produced in an ideal cycle time compared to the available time. The quality portion of the OEE metric represents the percentage of the products without defects produced out of the total number of produced parts. 


\section{ANALYSIS OF THE OVERALL EQUIPMENT EFFECTIVENESS AT THE SELECTED COMPANY}

The main task of the maintenance department in the enterprise is to ensure that equipment in the facility is operating correctly and efficiently. Another obligation which needs to be met is to maximize the life of equipment and to reduce the probability of failure. The medium-sized enterprise selected in this paper to discuss effects of CMMIS implementation represents a plasticprocessing industry company. It has recently started to follow the principles of TPM (total productive maintenance) in order to ensure the basic requirements for asset maintenance. The goal of TPM is to achieve zero breakdowns and zero defects related to equipment. The consequence of reducing breakdowns and defects is improvement on production rate, reduction in costs, reduction in inventory and eventually, increase in labour productivity. The aim of this chapter is to show the results of before and after implementing an information system comparing data from selected years (authors chose years 2006 and 2008, when the company didn't use any information system) and years 2009 and 2010 (after IS implementation) and give also background of information for other companies thinking about CMMIS implementation. The methodology is based on study and observation of previous papers and books published on this topic (see e.g. Vyskočil (2010), Legát (2013), Muchiri, P., Pintelon, L. (2008)).

\subsection{Methodology, Objective and Data Description}

For the analysis, we use data collected in the production plant of the selected medium-sized enterprise producing plastic components for the automobile industry. All data about the production time was collected continuously from 21 machines in two periods: in the first period by nominated workers; in the second period by the means of the newly implemented information system. These two periods differentiate in a method of data collection and are more described below.

The data provided information about availability, performance and the quality of the facility which could be quantified in OEE metrics. The metrics show the level of overall utilization of the facilities. The trend of utilization should be monitored and improved by implementing appropriate managerial decisions.

Period 1 was from 1.1.2006 till 31.12.2006 and 1.1.2008 till 31.12.2008. Within this period the researchers collected data about downtimes from workers (setters or service engineers) in every working shift. The hand written records included information about the type of machine; the type of downtime and the length of time machines were out of order.

Period 2 was from 1.1.2009 - 31.12.2010. It focused on the monitoring of data by CMMIS (computer-aided maintenance management information system). The system was implemented in order to enable the enterprise to manage supporting activities effectively.

This was the starting point for the authors of the article, who decided to measure changes in hours of downtimes in selected years to discuss effects of CMMIS implementation on this particular example. 


\subsection{Time Data Analysis of Production Downtimes}

Initially there were 21 machines in the plant in 2006, which were operated by four workers (two specialists for repairs, two setters). From the data in Table 2, we can identify these measurements: available time for 21 machines, effective available time for 21 machines, time taken for TPM and total lost time when machines were out of order for whatever reason. The values for 2006 are listed in Table 2.

Tab. 2 - Working time structure in 2006. Source: author's own.

\begin{tabular}{|l|c|c|}
\hline Production time & Hours & Percentage \\
\hline Effective time fund of 21 machines & 72516 & $88 \%$ \\
\hline Time for TPM & 5769 & $7 \%$ \\
\hline Lost time (non-functional machines) & 4120 & $5 \%$ \\
\hline Usable time fund for 21 machines & $\mathbf{8 2 ~ 4 0 5}$ & $\mathbf{1 0 0} \%$ \\
\hline
\end{tabular}

Based on the handwritten records from 2006 we found that the total working time of machines, T1, was only $88 \%$ from the total available time (there is no optimal value for availability, but 100 $\%$ is presumed to be the target in most manufacturing companies). Time taken for TPM (total productive maintenance) was $7 \%$ and lost time due to non-functional machines was $5 \%$. A significant time period in the work shift ( $5 \%$ of production time) when the machines were out of order due to breakdown or unplanned adjustment was a signal for continuous monitoring of the facility. The decision to monitor the downtimes of the machines should help the enterprise to uncover bottlenecks and potential for improvement in the maintenance regime.

The hand written record method used for recording the data in this company in 2006 and 2008 identified an insufficient level of TPM as the main bottleneck, as well as a too slow changeover of tools in $\mathrm{m}$ any cases.

As a result of these findings, the management decided to implement a computer-aided maintenance management system in order to monitor and analyse all maintenance operations. The system started to operate in January 2009. The following analysis compares the data collected in two different periods: in 2006 and 2008 without information management system (Period 1) and in 2009 and 2010 after its implementation (Period 2).

\subsection{Implementation of the CMMIS in the Enterprise}

The information system was intended to help maintenance workers (or setters) identify which machines require maintenance. It also gives appropriate information to management about the current situation in the workplace. Others functions of the system are work scheduling, TPM scheduling, reserving materials, recording costs and tracking relevant information such as the cause of the problem.

The operators, having identified themselves via the chip readers, manually input data about the process (for example the kind of rejects, the type of the downtime) into the system. If there is some downtime, the staff responsible for facility maintenance is contacted on the "help desk" by telephone, email or by a siren from the particular facility. The current data about machine utilization and efficiency is displayed directly at the workplace to keep the staff informed. For this purpose, screens and LED displays are used as a part of visualization management as well. 


\subsection{Downtimes Analysis}

The data collected by the two different methods in the two selected periods (years 2006 and 2008 and 2009 and 2010) were analyzed by Pareto analysis in order to identify the most significant downtimes according to time consumption. The duration of the downtime was chosen as the criterion for the Pareto analysis. The longer the facility is out of order due to unplanned maintenance, the more the production costs increase. Based on the total duration of the downtimes, 20 $\%$ of the key causes of downtimes were the same in both years. Namely, they were mechanical failure (downtime 21), electrical device failure (downtime 22) and other technical failure of the equipment (downtime 65). The total duration of key downtimes and their comparison in 2008 and 2009 are shown in Table 3 and Figure 1.

Tab. 3 - Overview of total length of time of selected downtimes in 2006, 2008, 2009 and 2010. Source: author's own.

\begin{tabular}{|l|c|c|c|c|}
\hline & $\mathbf{2 0 0 6}$ & $\mathbf{2 0 0 8}$ & $\mathbf{2 0 0 9}$ & $\mathbf{2 0 1 0}$ \\
\hline downtime 21 & 1509,66 & 1258,05 & 577,24 & 594,55 \\
\hline downtime 22 & 2419,78 & 2016,49 & 1092,85 & 983,57 \\
\hline downtime 65 & 154,82 & 92,71 & 264,07 & 132,03 \\
\hline Sum [hours] & $\mathbf{4 0 8 4 , 2 6}$ & $\mathbf{3 3 6 7 , 2 4}$ & $\mathbf{1 9 3 4 , 1 6}$ & $\mathbf{1 7 1 0 , 1 5}$ \\
\hline
\end{tabular}

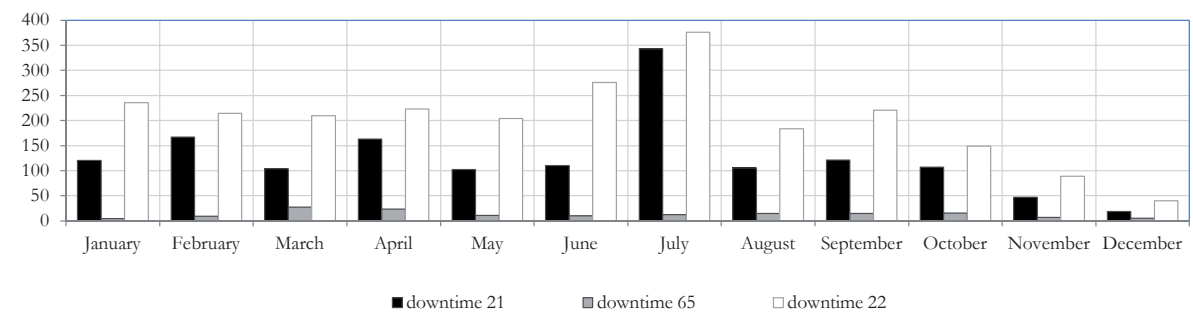

Fig. 1 - The amount of downtime in hours in 2006. Source: author's own.

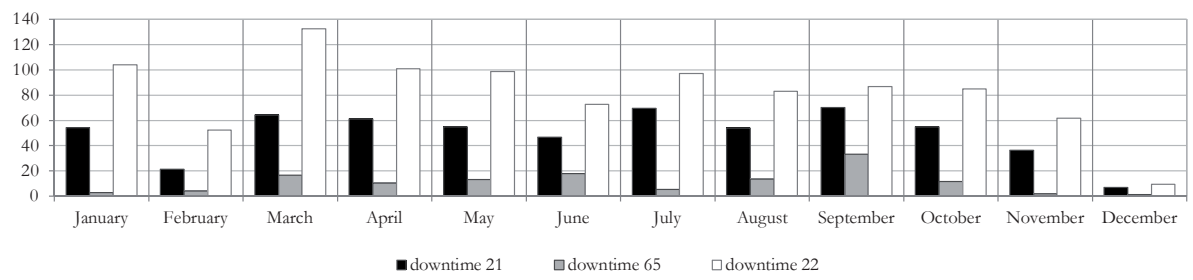

Fig. 2 -The amount of downtime in hours in 2010. Source: author's own. 
A comparison of the amount of downtime in the years 2006, 2008, 2009 and 2010 in Figure 1 and 2 and in the Table 3 shows that there is a significant decrease in the duration of downtimes 21 and 22 in 2009 and 2010. Concerning development of the downtime 65 (other technical failure of the equipment), the level of values is fluctuating during the monitored time period. This fluctuation was caused by the circumstances that cannot be influenced or improved by monitoring of CMMIS, the origin of downtimes is different (eg. setting or replacing of the machines due to changes in production).

Based on results of a previous study mentioned by Legát (2013) the authors considered the implemented CMMIS as a tool for improvement of the production system in selected company. As Legát points out, the CMMIS enables to management of an enterprise to check and inspect the machines and to reduce the number and duration of the downtimes more efficiently. Following the TPM principles and implemented more frequent quality controls are the causes for improving OEE indicator and leading a significant decrease in duration of downtimes. The evaluation of the effect of implementing a maintenance information system on the efficiency of production facilities was also a part of the large research study conducted already in 2001 - 2003 by Czech University of Life Sciences in Prague. As a result of this study it was found that handwritten records of the maintenance operations are insufficient and inaccurate. It is necessary to monitor and evaluate data and records from the CMMIS continuously. The system helps to evaluate metrics like OEE and others which can lead to significant maintenance cost reduction connected mainly with elimination of downtimes (Legát, 2013). This assumption was used in our further analysis.

\subsection{Reporting: Results and discussion}

Since 2009 the data in the company has been saved in the database of the CMMIS for further processing in reports and statistical analysis. Tabular and graphical reports are generated by this database and are made accessible for all responsible personnel and management via the intranet. As Dwyer (2008) mentions, OEE metrics are commonly used in many enterprises as a key performance indicator (KPI) in conjunction with lean manufacturing efforts to provide an indicator of success and benchmarking with other enterprises in the field. Also Samuel points out that OEE metric has become widely accepted as a quantitative tool essential for measurement of productivity in manufacturing operations (Samuel et al.,2002). Related to the literature overview in chapter 2, OEE metrics quantifies how a facility performs according to its designed capacity, the time periods when it is planned to run and the amount of scrap.

For the analysis of process efficiency the authors used the metrics mentioned in chapter 2 and its calculations:

coefficient of availability,

availability $=\frac{\text { uptime }}{\text { available time }}$

coefficient of performance,

performance $=\frac{\text { parts produced } * \text { ideal cycletime }}{\text { availabletime }}$ 
coefficient of quality

$$
\text { quality }=\frac{\text { parts without defects }}{\text { total amount of produced parts }}
$$

From the total number of 21 machines, 7 were randomly selected in order to analyze the development of the OEE metrics related to the implementation of the CMMIS. Based on the development of this key criterion (OEE), data from tables 4 and 5 show results of criterion in selected years.

Tab. 4 - Analysis of process efficiency on selected machines in 2006 and 2008. Source: author's own.

\begin{tabular}{|l|c|c|c|c|c|c|c|c|}
\hline Machine & $\mathrm{C}_{\mathrm{A} 2006}$ & $\mathrm{C}_{\mathrm{P} 2006}$ & $\mathrm{C}_{\mathrm{Q} 2006}$ & $\mathbf{O E E}_{2006}$ & $\mathrm{C}_{\mathrm{A} 2008}$ & $\mathrm{C}_{\mathrm{P} 2008}$ & $\mathrm{C}_{\mathrm{Q} 2008}$ & $\mathbf{O E E}_{\mathbf{2 0 0 8}}$ \\
\hline $\mathrm{V} 3531 / 80$ & $95 \%$ & $99 \%$ & $98 \%$ & $\mathbf{9 2} \%$ & $95 \%$ & $100 \%$ & $100 \%$ & $\mathbf{9 5 \%}$ \\
\hline $\mathrm{V} 3531 / 81$ & $98 \%$ & $96 \%$ & $99 \%$ & $\mathbf{9 3} \%$ & $97 \%$ & $96 \%$ & $100 \%$ & $\mathbf{9 3} \%$ \\
\hline $\mathrm{V} 4562 / 83$ & $99 \%$ & $99 \%$ & $99 \%$ & $\mathbf{9 7} \%$ & $99 \%$ & $99 \%$ & $99 \%$ & $\mathbf{9 7 \%}$ \\
\hline $\mathrm{V} 3963 / 101$ & $82 \%$ & $95 \%$ & $94 \%$ & $\mathbf{7 4} \%$ & $82 \%$ & $96 \%$ & $96 \%$ & $\mathbf{7 6} \%$ \\
\hline $\mathrm{V} 3963 / 102$ & $80 \%$ & $98 \%$ & $97 \%$ & $\mathbf{7 6} \%$ & $82 \%$ & $98 \%$ & $97 \%$ & $\mathbf{7 7 \%}$ \\
\hline $\begin{array}{l}\text { VHN4651/ } \\
111\end{array}$ & $96 \%$ & $93 \%$ & $99 \%$ & $\mathbf{8 8} \%$ & $96 \%$ & $92 \%$ & $99 \%$ & $\mathbf{8 8} \%$ \\
\hline $\begin{array}{l}\text { VHN4651/ } \\
112\end{array}$ & $90 \%$ & $87 \%$ & $99 \%$ & $\mathbf{7 7 \%} \%$ & $91 \%$ & $87 \%$ & $99 \%$ & $\mathbf{7 8 \%}$ \\
\hline
\end{tabular}

Notes: $C_{A}$ - coefficient of availability, $C_{P}$ - coefficient of performance, $C_{Q}$ - coefficient of quality

Tab. 5 - Analysis of process efficiency on selected machines in 2009 and 2010. Source: author's own.

\begin{tabular}{|l|c|c|c|c|c|c|c|c|}
\hline Machine & $\mathrm{C}_{\mathrm{A} 2009}$ & $\mathrm{C}_{\mathrm{P} 2009}$ & $\mathrm{C}_{\mathrm{Q} 2009}$ & $\mathbf{O E E}_{2009}$ & $\mathrm{C}_{\mathrm{A} 2010}$ & $\mathrm{C}_{\mathrm{P} 2010}$ & $\mathrm{C}_{\mathrm{Q} 2010}$ & OEE $_{2010}$ \\
\hline $\mathrm{V} 3531 / 80$ & $95 \%$ & $100 \%$ & $100 \%$ & $\mathbf{9 5} \%$ & $96 \%$ & $99 \%$ & $100 \%$ & $\mathbf{9 5 \%}$ \\
\hline $\mathrm{V} 3531 / 81$ & $97 \%$ & $98 \%$ & $100 \%$ & $\mathbf{9 5} \%$ & $97 \%$ & $99 \%$ & $100 \%$ & $\mathbf{9 6 \%}$ \\
\hline $\mathrm{V} 4562 / 83$ & $99 \%$ & $100 \%$ & $99 \%$ & $\mathbf{9 7} \%$ & $99 \%$ & $100 \%$ & $99 \%$ & $\mathbf{9 7 \%}$ \\
\hline $\mathrm{V} 3963 / 101$ & $86 \%$ & $96 \%$ & $99 \%$ & $\mathbf{8 1} \%$ & $88 \%$ & $98 \%$ & $98 \%$ & $\mathbf{8 5} \%$ \\
\hline $\begin{array}{l}\mathrm{V} 3963 / \\
102\end{array}$ & $90 \%$ & $99 \%$ & $98 \%$ & $\mathbf{8 6} \%$ & $92 \%$ & $99 \%$ & $98 \%$ & $\mathbf{8 9} \%$ \\
\hline $\begin{array}{l}\text { VHN4651/ } \\
111\end{array}$ & $98 \%$ & $93 \%$ & $99 \%$ & $\mathbf{9 0} \%$ & $98 \%$ & $93 \%$ & $99 \%$ & $\mathbf{9 0} \%$ \\
\hline $\begin{array}{l}\text { VHN4651/ } \\
112\end{array}$ & $93 \%$ & $88 \%$ & $99 \%$ & $\mathbf{8 1} \%$ & $93 \%$ & $90 \%$ & $99 \%$ & $\mathbf{8 3} \%$ \\
\hline
\end{tabular}


Tab. 6 - Development of the OEE metrics on selected machines from 2006 to 2010. Source: author's own.

\begin{tabular}{|l|c|c|c|c|}
\hline Machine & OEE 2006 & OEE 2008 & OEE 2009 & OEE 2010 \\
\hline V3531/80 & $92 \%$ & $95 \%$ & $95 \%$ & $95 \%$ \\
\hline V3531/81 & $93 \%$ & $93 \%$ & $95 \%$ & $96 \%$ \\
\hline V4562/83 & $97 \%$ & $97 \%$ & $97 \%$ & $97 \%$ \\
\hline V3963/101 & $74 \%$ & $76 \%$ & $81 \%$ & $85 \%$ \\
\hline V3963/102 & $76 \%$ & $77 \%$ & $86 \%$ & $89 \%$ \\
\hline VHN4651/111 & $88 \%$ & $88 \%$ & $90 \%$ & $90 \%$ \\
\hline VHN 4651/112 & $77 \%$ & $78 \%$ & $81 \%$ & $83 \%$ \\
\hline
\end{tabular}

Table 6 compares OEE metrics in these years. Presented numbers show that the trend in overall equipment effectiveness after implementation of the CMMIS is improving for machines V3531/81, V3963/101, V3963/102, VHN4651/111, VHN 4651/112. The progress in the level of the OEE metrics that can be seen in Table 6 reaches the target of $85 \%$ as mentioned by Dwyer (2008) for almost all machines except from VHN 4651/112. The level OEE for VHN 4651/112 is caused by insufficient care of the maintenance staff, mainly because this machine is not always producing parts in an ideal cycle time compared to the available time due to production plan. On the other hand machines V3531/80 and V4562/83 have been already achieving good and stable results in their OEE metrics since 2008, the reason for this is the long-term following of TPM principles at this particular machines.

Based on the findings from the data analysis in this particular case study from the selected enterprise supported with the findings from the previous research of the team of prof. Legát at Czech University of Life Sciences in Prague and other relevant sources from the professional literature mentioned above, managerial targets for achieving better performance can be set as follows:

1. Categorization of downtime according to criteria of their origin in order to achieve a decrease of number of downtimes by quality control tools,

2. Increased utilization of the OEE metrics (Overall Equipment Effectiveness) that regard availability, performance and quality of the process in order to control the equipment and facility more efficiently.

3. Decreased costs of production and maintenance - calculating the cost of machine breakdowns with the help of a CMMIS can potentially lead to better allocation of enterprise's resources.

4. Increased working time of the tools by means of available technological and material innovations (like CMMIS).

5. Implementation of regular maintenance checks (planned, preventative and autonomous) that ensure working time and safety maintenance of the facility.

6. Stabilization of production processes which includes several aspects like setting standards of production time, standards for machine adjustment and changeover of the tools. 


\subsection{Discussion}

The implementation of the CMMIS as demonstrated in the example of the selected enterprise (see Table 6 and Figure 1 and 2) shows an increase in the utilization of the facility and, in most cases, improvement of the OEE metric. This is accompanied (also in case of our selected enterprise) by an increase in the volume of production, labour productivity and a reduction in production and maintenance costs as Šteker (2012) also points out. On the other hand, the costs of implementing the CMMIS can be counted in particular cases in millions of crowns and the return on such an investment can take a number of years. Management of enterprises has to take this into account and weight such a decision carefully. Calculation of the costs for CMMIS implementation is not a part of this paper and it could be the topic for further research. However, it is the reason the management of the enterprise should consider all the aspects of the information system before its implementation.

As was discussed in the paper for manual data collection, accuracy is very low since recording of some minor stoppages or downtime can often be forgotten. Parsec (2005) arguments that though the cost of manual data collection is minimal, detailed manual data collection may demotivate the personnel and lead to reaction against the measurements. With the use of MES (manufacturing execution system), CMMIS and ERP (enterprise resource planning), collection of OEE related data is automated in some manufacturing enterprises. Though the cost associated to these installations is considerable, the data accuracy is high and the data collection process is simplified. Introduction of these modern software tools is been leveraged to produce sophisticated real time reports that allow manufacturers to fully understand all their sources of lost productivity (Parsec, 2005).

However to focus on OEE metrics Muchiri, P., Pintelon, L. (2008) point out that some important measures (e.g. cost and flexibility) are not measured in the OEE. This is reason why other metrics (like associated maintenance index) should also be involved in further research. The impact on development of the metrics can have also other factors. Trained and experienced staff, amortization of the manufacturing facility or effective production planning should be also considered. With the adoption of this new automated technology of data capturing, the areas of lost production time will be easily identified. (Muchiri,P., Pintelon, L. 2008)

Situation in an enterprise and the results of OEE metrics in maintenance can generally be influenced not only by CMMIS implementation but also with other factors as financial demands of maintenance of equipment, level of equipment utilisation or value of reserves in spare parts. However in our particular enterprise all these factors were stable during our research.

\section{CONCLUSION}

Exact information about the true state of the facility and its technical and economical parameters has had a significant impact on the management decision-making process these days. That is why management information systems are being implemented so frequently nowadays. This paper offers a brief overview of the topics of facility management using a theoretical literaturebased framework in this field at first. Then it focuses on the area of maintenance and importance 
of information system implementation. The empirical case study from the area of FM dealing with maintenance has been presented on purpose to show the effect of CMMIS implementation on the enterprise. In order to analyse the impact of the implementation of the maintenance information system, we used primary data collected in the given enterprise in two periods: before the information management system was implemented; and after its implementation. Using this qualitative data and selected metrics, this study proved that providing support via a maintenance information system helps the enterprise to reach a better level of OEE metrics. Despite the limitations of this data set, the results provide better insights on the production processes and point out the importance of using information systems in facility management and confirm statements given in previous studies (Legát, Vyskočil, Parsec etc.). However each company also needs to take into account the costs connected with CMMIS implementation which are usually significant. To see the total effect it is necessary to compare the savings from the reduction of downtime, decreasing costs etc. with the total cost connected with CMMIS implementation. This was not a part of the analysis in this paper but it could be the stepping-stone for further research as well as an inspiration for a deeper analysis with a larger amount of data from enterprises and a wider industrial context.

\section{References}

1. Alexander, K. (1996). Facilities management: Theory and Practice. London: E.\&F.N. Spon.

2. Becker, F., \& Steele, F. (1990). The Total Workplace. Facilities, 8(3), 9-14. http://dx.doi. org/10.1108/EUM0000000002099

3. Curcio, S. (2003). Lessico del facility management. Milan, Italy : Il Sole 24 Ore.

4. Dal, B., Tugwell, P., \& Greatbanks, R. (2000). Overall Equipment Effectiveness as a measure of operational improvement. International Journal of Operational and Production Management, 20(12), 1488-1502. http://dx.doi.org/10.1108/01443570010355750

5. Dwyer, J. (2008). OEE - The Great Energy Saving. The Manufacturer, 2008(February), 52-55. Retrieved from: http://www.idhammarsystems.com/uploaded_images/docs/ t4p44c6OEE_\%20The\%20Great\%20Saving_The\%20Manufactuer_Web.pdf

6. EuroFM (2013a). What is FM? Retrieved from: http://www.eurofm.org/about-us/what-is$\mathrm{fm} /$

7. EuroFM (2013b). EN15221. Retrieved from: http://www.eurofm.org/knowledge/en15221/

8. Guizzi, G., Miele, D., \& Carlini, R. (2012). Facility Management: a literature review. In. Proceedings of the 6th WSEAS European Computing Conference, 423-429.

9. Havlík, R. (2011). Multi-criteria scheduling approach for e-maintenance system, Proceedings in Manufacturing Systems, 6(2), 91-96.

10. Holásek, L. (2009). Zkušenosti managementu v rámci reengeneeringu ČKD. Praha: SP MUVS.

11. Jurča, V. (2004). Možnosti využití a zpracováni dat z ř́zenení údržby. Praha: Česká společnost pro jakost.

12. Kincaid, D. (2006). Integrated Facility Management. Facilities, 12(8), 20-23. http://dx.doi. org/10.1108/02632779410062353 
13. Legát, V. (2013). Management a inženýrství údržby. Praha: Professional Publishing.

14. Lewis, B., \& Payant, R. (2007). Facility Manager's Maintenance Handbook. New York: McGrawHill Professional.

15. Miler, A. (2007). What is Facility Management? Retrieved from: http://www.bmswebsite. com/index_files/What_is_Facility_Management.pdf

16. Muchiri, P., \& Pintelon, L. (2008). Performance measurement using overall equipment effectiveness (OEE): Literature review and practical application discussion. International Journal of Production Research, 46(13), 3517-3535. http://dx.doi.org/10.1080/002075406011426 45

17. Muller, A., Marquez, A. C., \& Lung, B. (2008). On the concept of e-maintenance: Review and current research. Reliability Engineering \& System Safety, 93(8), 1165-1187. http://dx.doi. org/10.1016/j.ress.2007.08.006

18. Nakajima, S. (1988). An Introduction to TPM. Portland: Productivity Press.

19. Nenadál, J. (2004). Mérení v systémech jakosti. Praha: Management Press.

20. Pala, F., \& Melzi, E. (2009). Facility Management Organizational Models. In. R. Franciosi (Ed.), Open Facility Management - A successful implementation in a public administration (84-204). Italy: Scuola Nazionale Servizi.

21. Pala F., \& Prister P. (2004). Facility Management e Creazione del Valore. Italy, Milano: IFMA.

22. Parsec A. C. (2005).The bidden pitfalls of doing back of the envelope calculations to determine your current OEE. Retrieved from: www.parsec-corp.com

23. Reyes, G. A. et.al (2010). Overall equipment effectiveness (OEE) and process capability (PC) measures: A relationship analysis. The International Journal of Quality \& Reliability Management, 27(1), 48-62. http://10.1108/02656711011009308

24. Huang, S. H., Dismukes, J. P., Shi, J., Qi, S., \& Robinson, D. E. (2002). Manufacturing system modelling for productivity improvement. Journal of Manufacturing Systems, 21(4), 249259. http://dx.doi.org/10.1016/S0278-6125(02)80165-0

25. Sapp, D. (2011). Facilities Operations \& Maintenance. Retrieved from: http://www.wbdg. org/om/om.php

26. Schürle, T., \& Fritsch, D. (2000). CAFM Data Structures: a Review and Examples. International Archives of Photogrammetry and Remote Sensing, 33(B4), 909-916.

27. Šteker, K. (2012). Analysis of the Usage of Information Systems for Economic Process Management in Czech Companies. Journal of Competitiveness, 4(3), 77-91. http://dx.doi. org/10.7441/joc.2012.03.06

28. Štrup, O. (2012). Současný stav facility managementu v EU. Časopis Facility manager, 1, 4-5.

29. Vetráková, M., Potkány, M., \& Hitka, M. (2013). Outsourcing of Facility Management. E+M Ekonomie a Management, 11(1), 80-92.

30. Vyskočil, V. (2010). Management podpuirných procesü. Př́ibram: Professional Publishing.

31. Wakjira, W.M., \& Singh, A.P. (2012). Total Productive Maintenance: A Case Study in Manufacturing Industry. Global Journal of researches in engineering, 12(1), 25-32.

32. Wireman, T. (2005). Developing Performance Indicators for Managing Maintenance. New York: Industrial Press. 


\section{Contact information}

Ing. Eva Šlaichová, Ph.D., Ing. Katerina Marš̌ková, Ph.D.

Technical University of Liberec

Faculty of Economics, Department of Business Administration

Studentskéa 2, 461 17, Liberec, Czech Republic

E-mail:eva.slaichova@tul.cr; katerina.marsikova@tul.cz. 